\title{
International Financial Reporting Standards (IFRS) for International Accounting and Financial Integration: With special focus on Wipro Limited of India
}

\author{
Dr. Ehtesham Husain Abbasi \\ Assistant Professor, Department of Accounting \\ College of Business, King AbdulAziz University, Rabigh, Kingdom of Saudi Arabia,
}

\begin{abstract}
There is a growing international consensus on the International Financial Reporting Standards (IFRS) as acceptable standards for assessment of the financial health of a company across the globe. With the world becoming a global village, companies and investors who operate business in several countries need to understand each nation's accounting principle. Although basic accounting principles such as the accrual basis and the going-concern assumption are widely accepted, the application of these principles in different economic and cultural environments has led to significant differences as to how accountants report similar transactions. Local differences exist in, for example, the treatment of goodwill, the definition of a group, treatment of borrowing costs, measurement of impairment, and the treatment of deferred taxes. The author considered the Annual reports of Wipro Limited of India. Where in the reconciliation of the equity as per IFRS and Indian Generally Accepted Accounting Principles (IGAAP) were reported for the year beginning 2010 and for the year ended 2011. The 2011-2012 Annual Reports of Wipro presented the consolidated financial statement in both Indian GAAP and IFRS. Reconciliation of equity as per IFRS and IGAAP was reported for the year beginning 2010 and for the year ended 2011, which is considered in this study for examination.
\end{abstract}

Keywords: International Financial Reporting Standards (IFRS), Indian Generally Accepted Accounting Principles (IGAAP), Wipro Limited, International Accounting Standards Board (IASB)

\section{INTRODUCTION}

There is a growing international consensus on the International Financial Reporting Standards (IFRS) as acceptable standards for assessment of the financial health of a company across the globe. With the world becoming a global village, companies and investors who operate business in several countries need to understand each nation's accounting principle. Although basic accounting principles such as the accrual basis and the going-concern assumption are widely accepted, the application of these principles in different economic and cultural environments has led to significant differences as to how accountants report similar transactions. Local differences exist in, for example, the treatment of goodwill, the definition of a group, treatment of borrowing costs, measurement of impairment, and the treatment of deferred taxes.

For entities that are globally active, these differences in financial reporting requirements create extra complications in terms of preparing, consolidating, auditing, and interpreting financial statements. This is because financial statements have to be reconciled before 
consolidated financial statements can be prepared, the analysis of potential acquirers in a foreign country increases the costs of the mergers and acquisitions department because they have to familiarize themselves with a foreign accounting system, and investors have to be informed about differences in financial reporting. In general, the differences in accounting treatments create non-optimal information for users of financial statements, which in turn leads to less than optimal allocation of resources. It has been said that accounting is the "language of business," and though not all users need to create the language, all users should be able to "read" the language. For decades, however, it has been difficult to read and understand company performance when financial information originated from different global locations. Many of these companies effectively prepared financial statements under different accounting rules and regulations. As a result, the different rules created different values or measures for the same economic event. [1]

In India, the Institute of Chartered Accountants of India (ICAI) has made IFRS mandatory in India for financial statement from 1st April 2011. [35] The rules for the first-time adoption of IFRS are set out in IFRS 1 -First time-adoption of International Financial Reporting Standards. IFRS 1 states that a company should use the same accounting policies in its opening balance sheet and throughout all periods presented in its IFRS financial statements. The standard requires these policies to comply with IFRS effective at the reporting date of the first published financial statements under IFRS. IFRS 1 permits certain mandatory exemptions and also allows exemptions from the application of certain IFRS in order to assist companies with the transaction process. According to an Oracle White Paper (2008) the International Accounting Standards Board (IASB) has since 1970 worked to develop a single set of International Standards, the IFRS. The world's capital market ebb and flow continuously, and participants in that market place must have access to financial information that factually reflects their economic performance, is consistent among companies around the globe, and is governed by a trusted and respected authority of corporate compliance. [4]

Beginning from 1st April 2011, Companies listed in National Stock Exchange(Nifty 50), Bombay Stock Exchange(Sensex 30),Companies whose stocks are listed outside India and Companies which are listed or not but which have their net worth exceeding INR 1000 crores are required to carry out the convergence of Indian Accounting Standard with IFRS. [35] Reliable, consistent and uniform financial reporting is important part of good corporate governance practices worldwide in order to enhance the credibility of the businesses in the eyes of investors to take informed investment decisions. In pursuance of G-20 commitment given by India, the process of convergence of Indian Accounting Standards with IFRS has been carried out in Ministry of Corporate Affairs through wide ranging consultative exercise with all the stakeholders. International Financial Reporting Standards (IFRS) have recently emerged as the numero uno accounting framework, with widespread global acceptance. The IASB, a private sector body, develops and approves IFRS. The IASB replaced the IASC in 2001. The IASC issued IAS from 1973 to 2000. Since then, the IASB has replaced some IAS with new IFRS and has adopted or proposed new IFRS on topics for which there was no previous IAS. Through committees, both, the IASC and the IASB have issued interpretations of standards.

IFRS refers to the new numbered series of pronouncements that the IASB is issuing, as distinct from the IAS series issued by its predecessor. More broadly, IFRS refers to the entire body of IASB pronouncements, including standards and interpretations approved by the IASB, IFRIC, IASC and SIC. Currently, 41 IAS and 9 IFRS are effective. In addition, 11 SICs and 16 IFRICs provide guidance on interpretation issues arising from IAS and IFRS.IFRS is principle based, drafted lucidly and is easy to understand and apply. However, the application of IFRS requires 
an increased use of fair values for measurement of assets and liabilities. The focus of IFRS is on getting the balance sheet right, and hence, can bring significant volatility to the income Statement.

\section{OBJECTIVES}

The prime objective of the present work is to study impact and consequences on financial statement due to IFRS adoption with the help of case study of Wipro Limited.

More specifically, this article has the following objectives:

1. To observe the effects of voluntary convergence of IFRS on financial statement of Wipro Ltd, an IT based company.

2. To scrutinize the effects of voluntary convergence of IFRS on financial ratio of Wipro Ltd.

\section{Study Area}

\section{RESEARCH METHODOLOGY}

This study has been conducted by incorporating the provisions of IFRS adopted / to be adopted by the Wipro Ltd, a software company running business in India.

\section{Research Design}

This study is analytical as well as descriptive in nature. The study gives the comparative details about the IFRS and IGAAP for the purpose of better understanding and analysis. We have not taken any hypotheses in the study because adoptions of IFRSs are in progress and it takes time to come in full-fledged manner.

\section{Data Collection}

The study is based on secondary data on selected variables sourced from the published annual reports of Wipro for the year ended 31st March 2012. Wipro had voluntarily prepared its annual report on the basis of Indian GAAP and IFRS for the year ended 31st March 2008 \& 31st March 2012, wherein reconciliation of equity based on Indian GAAP and IFRS is presented for the opening Balance Sheet as at 1st April 2010 and for Balance Sheet ended 31st March 2011.The main sources of secondary data are company's manual, annual general reports, journals, newspapers and concerned websites.

\section{Data Analysis}

Comparative study and chart has been prepared for bird's eye view. Since the data has been analyzed and provided by the company itself, we have elaborated the reasons behind the differences and suggested tentative solutions towards better convergence of IFRS.

\section{Table.1 How IFRS was implemented: Road Map I}

Companies other than Insurance companies, Banking companies and Non-Banking finance companies

\begin{tabular}{|c|c|c|}
\hline Applied to & Applicability & Not applied to \\
\hline $\begin{array}{l}\text { Phase I :- (i) NSE-Nifty } 50 \text { and BSE-Sensex } 30 \\
\text { companies } \\
\text { (ii) Companies listed in overseas stock exchanges } \\
\text { (iii) Companies with net worth above INR } 1000 \text { crore }\end{array}$ & $\begin{array}{l}\text { 1st April, } \\
2011\end{array}$ & $\begin{array}{l}\text { (i) Unlisted companies having a net worth } \\
\text { of INR } 500 \text { crore or less and whose } \\
\text { securities are not listed overseas } \\
\text { (ii)Small and medium companies (SMCs) } \\
\text { They can voluntarily opt to follow the } \\
\text { converged Accounting Standards }\end{array}$ \\
\hline $\begin{array}{l}\text { Phase II :-Companies whether listed or not having a net } \\
\text { worth exceeding INR } 500 \text { crore but not above INR } 1000 \\
\text { crore }\end{array}$ & $\begin{array}{l}\text { 1st April, } \\
2013\end{array}$ & \\
\hline
\end{tabular}


Phase III :- Listed companies having a net worth of INR 1 st

* When the accounting year ends on a date other than 31st March, the conversion of the opening Balance Sheet will be made in relation to the first Balance Sheet which is made on a date after 31st March.

Source: http://www.icai.org/

Table 2. How IFRS was implemented: Road Map II

\begin{tabular}{|c|c|c|}
\hline Applied to & $\begin{array}{l}\text { Date of } \\
\text { Applicability }\end{array}$ & Not applied to \\
\hline $\begin{array}{l}\text { Phase } \\
\text { (i)All insurance companies }\end{array}$ & 1st April,2012 & $\begin{array}{l}\text { (i) Urban co-operative banks having net worth } \\
\geq 200 \text { crore and regional rural banks } \\
\text { (ii) Listed NBFCs and unlisted NBFCs, not } \\
\text { being part of Nifty and Sensex, with net worth } \\
\text { above } 500 \text { crore } \\
\text { (iii)Unlisted NBFCs having a net worth of INR } \\
500 \text { crore or less. } \\
\text { They can voluntarily opt to foll w the } \\
\text { converged accounting standards }\end{array}$ \\
\hline $\begin{array}{l}\text { Phase } \\
\text { (ii)(a) NSE-Nifty } 50 \text { or BSE- Sensex } 30 \text { NBFCs. } \\
\text { and NBFCs, listed or not, having a net worth } \\
\text { above Rs } 1000 \text { crore. } \\
\text { (b)Scheduled commercial banks and urban co- } \\
\text { operative banks with net worth net worth above } \\
\text { INR } 300 \text { crore }\end{array}$ & 1st April,2013 & \\
\hline $\begin{array}{l}\text { Phase } \\
\text { (iii)Urban co-operative banks having a net worth } \\
\text { in excess of INR } 200 \text { crore but not exceeding } 300 \\
\text { crore }\end{array}$ & 1st April,2014 & \\
\hline
\end{tabular}

\section{Source: http://www.icai.org/}

After postponing its implementation once, India is again attempting to adopt International Financial Reporting Standards (IFRS). India originally decided to implement IFRS from 1 April 2011 in a phased manner but it was postponed. In January 2013, the ministry for corporate affairs (MCA) sought the opinion of the Institute of Chartered Accountant of India (ICAI) as to when India could converge to IFRS. ICAI gave its recommendations in February, suggesting that companies with net worth above Rs 1,000 crore should implement IFRS from 1 April 2015; those worth Rs 500-1,000 crore by 1 April 2016 and all others by 1 April 2017.

India has no choice but to adopt IFRS. More than 100 countries have already adopted IFRS, including China, Canada and Australia. Even US is now considering moving from US GAAP to IFRS. India is one of the few countries in the world which has yet to adopt IFRS or come out with a clear timeframe for the same. Many of India's peer countries have also implemented the IFRS- China (a couple of years ago), Brazil (in 2008) and Russia (in 2012). Japan is one of the few developed countries that have not yet implemented IFRS. The whole of Europe is already in the IFRS mode.

\section{Rationale behind adopting IFRS in Indian Accounting scenario}

A set of financial reporting standards issued by the International Accounting Standards Board is recognized under the brand name International Financial Reporting Standards (IFRSs). IFRS 
is a trade mark of the International Accounting Standards Committee Foundation. The main objective of International Financial reporting Standard (IFRS) is to harmonize accounting between countries which will make it easier to conduct business internationally and can subsequently raise funds in global capital market.

International Financial Reporting Standards (IFRSs) comprise of:

- International Financial Reporting Standards (IFRS)—standards issued after 2001

- International Accounting Standards (IAS)—standards issued before 2001

- Interpretations originated from the International Financial Reporting Interpretations Committee (IFRIC)-issued after 2001

- Standing Interpretations Committee (SIC)—issued before 2001

- Framework for the Preparation and Presentation of Financial Statements (1989)

Presently, there are nine IFRS, forty one IASs, eighteen IFRIC interpretations and twelve SIC interpretations (Given in Appendix). [35]

In general connotation, 'convergence' means to achieve harmony with IFRS; in precise term, convergence can be considered "to design and maintain national accounting standards in a way that financial statements prepared in accordance with national accounting standards draw unreserved statement of compliance with IFRS". In this context, attention is drawn to paragraph 14 of International Accounting Standard (IAS) 1, Presentation of Financial Statements, which states that financial statements shall not be described as complying with IFRS unless they comply with all the requirements of IFRS.

Thus, 'convergence with IFRSs' means adoption of IFRS.

\section{IFRS - A truly global accounting standard}

The year 2000 was significant for IAS, now known as IFRS. The International Organization of Securities Commission formally accepted the IAS core standards as a basis for cross-border listing globally. In June 2000, the European Commission passed a requirement for all listed companies in the European Union to prepare their CFS using IFRS (for financial years beginning 2005). Since 2005, the acceptability of IFRS has increased tremendously. There are now more than 100 countries across the world where IFRS is either required or permitted. This figure does not include countries such as India, which do not follow IFRS but whose national GAAP is inspired by IFRS.

The table below provides a snapshot of IFRS acceptability globally.

Table 3. Snapshot of IFRS acceptability

\begin{tabular}{|l|c|}
\hline Domestic listed entities & $\begin{array}{l}\text { Number of } \\
\text { countries }\end{array}$ \\
\hline IFRS required for all domestic listed companies & 85 \\
\hline IFRS permitted for domestic listed companies & 24 \\
\hline IFRS required for some domestic listed companies & 4 \\
\hline IFRS not permitted for domestic listed companies & 34 \\
\hline Total & $\mathbf{1 4 7}$ \\
\hline
\end{tabular}

Source: http://www.icai.org/ 


\section{Benefits of adopting IFRS for Indian companies}

The decision to converge with IFRS is a milestone decision and is likely to provide significant benefits to Indian corporates.

\section{Improved access to international capital markets}

Many Indian entities are expanding or making significant acquisitions in the global arena, for which large amounts of capital is required. The majority of stock exchanges require financial information prepared under IFRS. Migration to IFRS will enable Indian entities to have access to international capital markets, removing the risk premium that is added to those reporting under Indian GAAP.

\section{Enable benchmarking with global peers and improve brand value}

Adoption of IFRS will enable companies to gain a broader and deeper understanding of the entity's relative standing by looking beyond country and regional milestones. Further, adoption of IFRS will facilitate companies to set targets and milestones based on global business environment, rather than merely local ones.

\section{Escape multiple reporting}

Convergence to IFRS, by all group entities, will enable company managements to view all components of the group on one financial reporting platform. This will eliminate the need for multiple reports and significant adjustment for preparing consolidated financial statements or filing financial statements in different stock exchanges.

\section{Reflects true value of acquisitions}

In Indian GAAP, business combinations, with few exceptions, are recorded at carrying values rather than fair values of net assets acquired. Purchase consideration paid for intangible assets not recorded in the acquirer's books is usually not reflected separately in the financial statements; instead the amount gets added to goodwill. Hence, the true value of the business combination is not reflected in the financial statements. IFRS will overcome this flaw, as it mandates accounting for net assets taken over in a business combination at fair value. It also requires recognition of intangible assets, even if they have not been recorded in the acquirer's financial statements.

\section{Lower cost of capital}

Migration to IFRS will lower the cost of raising funds, as it will eliminate the need for preparing a dual set of financial statements. It will also reduce accountants' fees, abolish risk premiums and will enable access to all major capital markets as IFRS is globally acceptable.

\section{New opportunities will open up for corporates}

Benefits from the adoption of IFRS will not be restricted to Indian corporates. In fact, it will open up a host of opportunities in the services sector. With a wide pool of accounting professionals, India can emerge as an accounting services hub for the global community. As IFRS is fair value focused, it will provide significant opportunities to professionals including, accountants, valuers and actuaries, which in-turn, will boost the growth prospects for the $\mathrm{BPO} / \mathrm{KPO}$ segment in India.

\section{IFRS challenges}

Financial reporting systems must be amenable to change so that finance professionals can respond to investor and analyst with confidence. According to Oracle White Paper (2008) most 
companies are able to adopt a new accounting standard, but a truly successful transition depends on a company's ability to provide full audit trails, variance analysis, and reconciliation of prior standards to satisfy internal and external inquiries:

\section{Shortage of resources}

With the convergence to IFRS, implementation of SOX, strengthening of corporate governance norms, increasing financial regulations and global economic growth, accountants are most sought after globally. Accounting resources is a major challenge. India, with a population of more than 1 billion, has only approximately 145,000 Chartered Accountants, which is far below its requirement.

\section{Training}

If IFRS has to be uniformly understood and consistently applied, training needs of all stakeholders, including CFOs, auditors, audit committees, teachers, students, analysts, regulators and tax authorities need to be addressed. It is imperative that IFRS is introduced as a full subject in universities and in the Chartered Accountancy syllabus.

\section{Information systems}

Financial accounting and reporting systems must be able to produce robust and consistent data for reporting financial information. The systems must also be capable of capturing new information for required disclosures, such as segment information, fair values of financial instruments and related party transactions. As financial accounting and reporting systems are modified and strengthened to deliver information in accordance with IFRS; entities need to enhance their IT security in order to minimize the risk of business interruption, in particular to address the risk of fraud, cyber terrorism and data corruption.

\section{Distributable profits}

IFRS is fair value driven, which often results in unrealized gains and losses. Consideration of computing distributable profits will have to be debated, in order to ensure that distribution of unrealized profits will not eventually lead to reduction of share capital.

\section{Taxes}

IFRS convergence will have a significant impact on financial statements and consequently tax liabilities. Tax authorities should ensure that there is clarity on the tax treatment of items arising from convergence to IFRS. For example, will government authorities tax unrealized gains arising out of the accounting required by the standards on financial instruments? From an entity's point of view, a thorough review of existing tax planning strategies is essential to test their alignment with changes created by IFRS. Tax, other regulatory issues and the risks involved will have to be considered by the entities.

\section{Communication}

IFRS may significantly change reported earnings and various performance indicators. Managing market expectations and educating analysts will therefore be critical. A company's management must understand the differences in the way the entity's performance will be viewed, both internally and in the market place and agree on key messages to be delivered to investors and other stakeholders. Reported profits may be different from perceived commercial performance due to the increased use of fair values, and the restriction on existing practices such as hedge accounting. Consequently, the indicators for assessing both business and executive performance will need to be revisited. 


\section{Management compensation and debt covenants}

The amount of compensation calculated and paid under performance-based executive, and employee compensation plans may be materially different under IFRS, as the entity's financial results may be considerably different. Significant changes to the plan may be required to reward an activity that contributes to an entity's success, within the new regime. Renegotiating contracts that referenced reported accounting amounts, such as, bank covenants or FCCB conversion trigger, may be required on convergence to IFRS.

\section{First-time adoption of IFRS}

ICAI has announced convergence with IFRS for accounting periods commencing on or after 1 April 2011. As per the Announcement, all listed entities, public interest entities, such as banks, insurance entities and large-sized entities shall adopt IFRS. In addition, the Ministry of Corporate Affairs (MCA) had issued a press release in which the Ministry had committed to IFRS convergence from 1st April 2011.

Nearly all the studies highlighted the need of IFRS and how to move from country specific accounting standards to globally accepted reporting standards. In fact the above mentioned studies ignored the practical aspect, problems which a company might face while converging from country specific accounting standards to IFRS. There is very limited text which talked about implementation of the internationally recognized financial reporting standards i.e. IFRS. Therefore our study is based on to gauge the impact of adoption of IFRS and the problems a company face at the time of conversion period through case study of Wipro Limited. Few studies have been carried out in India with regard to convergence effect of IFRS on Indian companies.

\section{The Company overview}

Wipro Limited ("Wipro" or the "Parent Company"), together with its subsidiaries and equity accounted investees (collectively, "the Company" or the "Group") is a leading India based provider of IT Services, including Business Process Outsourcing ("BPO") services, globally. Further, Wipro has other businesses such as IT Products, Consumer Care and Lighting and Infrastructure engineering. Wipro is a public limited company incorporated and domiciled in India. The address of its registered office is Wipro Limited, Doddakannelli, Sarjapur Road, Bangalore - 560 035, Karnataka, India. Wipro has its primary listing with Bombay Stock Exchange and National Stock Exchange in India. The Company's American Depository Shares representing equity shares are also listed on the New York Stock Exchange. These consolidated financial statements were authorized for issue by Audit Committee on May 31, 2010.

\section{ANALYTICAL RESULTS}

\section{Impact of Convergence to IFRS on Financial Statements-study on Wipro Ltd}

Companies have started the process of preparing IFRS compliant financial statements and have already adopted the change in a timely manner. Few companies such as Wipro, Infosys Technologies, NIIT, Mahindra \& Mahindra, Tata Motors, Bombay Dyeing and Dr Reddy's Laboratories have already began to align their accounting standards to IFRS.

The author considered the Annual report of Wipro prepared for the year ended 31st March 2012 where in the reconciliation of the equity as per IFRS and Indian GAAP were reported for the year beginning 2010 and for the year ended 2011. The 2011-2012 Annual Report of Wipro presented the consolidated financial statement in both Indian GAAP and IFRS. Reconciliation of equity as per IFRS and Indian GAAP was reported for the year beginning 2010 and for the year ended 2011, which is considered in this study for examination. 
Table 4: Reconciliation of Profits between IFRS and Indian GAAP (INR in millions)

\begin{tabular}{|l|c|c|c|}
\hline & Notes & Fiscal 2012 & Fiscal 2011 \\
\hline $\begin{array}{l}\text { Profit after tax as per } \\
\text { Indian GAAP }\end{array}$ & A & $(259)$ & 38,999 \\
\hline $\begin{array}{l}\text { Intangible asset } \\
\text { amortization }\end{array}$ & B & 26 & $(43)$ \\
\hline $\begin{array}{l}\text { Difference in } \\
\text { revenue recognition } \\
\text { norms }\end{array}$ & C & 15 & $(101)$ \\
\hline $\begin{array}{l}\text { Stock Compensation } \\
\text { Expense }\end{array}$ & D & $(21)$ & $(75)$ \\
\hline Others & & $(140)$ & 13 \\
\hline Tax adjustments & 45,931 & 38,761 \\
\hline $\begin{array}{l}\text { Net Income as per } \\
\text { IFRS }\end{array}$ & & & \\
\hline
\end{tabular}

Source: Annual Report of Wipro, 2012.

Under IFRS, a portion of the purchase consideration in a business acquisition is allocated to intangible assets which meets the criteria for being recognized as an asset apart from goodwill. These intangible assets are amortized over their useful life in proportion to the economic benefits consumed in each reporting period. The increase in intangible amortization is primarily due to acquisition of CITI Technologies in fiscal 2011.

Under IFRS, revenue relating to product installation services is recognized when the installation services are performed. Under Indian GAAP, the entire revenue relating to the supply and installation of products is recognized when products are delivered since installation services are considered to be incidental / perfunctory to product delivery and the cost of installation services is also accrued upon delivery of the product.

Under IFRS, the Company amortizes stock compensation expense relating to share options which vest in a graded manner on an accelerated basis, as compared to straight-line basis under Indian GAAP.

Also under IFRS, the stock compensation expense is recognized net of expected attrition as compared to Indian GAAP, where stock compensation expense is reversed for options which do not vest due to attrition at actual.

This includes difference in accounting for certain foreign currency forward contracts and basis of interest capitalization under IFRS and Indian GAAP.

Table 5. Consolidated Financial Statement under IFRS of WIPRO Limited, Reconciliation of Equity as at April 1, 2010

\begin{tabular}{|l|l|l|l|l|l|}
\hline Particulars & $\begin{array}{l}\text { Amount as } \\
\text { per Previous } \\
\text { IGAAP }\end{array}$ & $\begin{array}{l}\text { Amount as } \\
\text { per IFRS } \\
\text { Transaction } \\
\text { to IFRS }\end{array}$ & $\begin{array}{l}\text { Ef } \\
\text { Change }\end{array}$ & $\begin{array}{l}\text { Relevant } \\
\text { Notes } \\
\text { adjustments } \\
\text { for }\end{array}$ \\
\hline Goodwill & 42209 & 42635 & $(426)$ & $(1.01)$ & 8 \\
\hline PPE and Intangibles & 41583 & 41344 & 239 & 0.57 & 1,2 \\
\hline $\begin{array}{l}\text { Available for Sales } \\
\text { investment }\end{array}$ & 14679 & 15247 & $(568)$ & $(3.87)$ & 3 \\
\hline $\begin{array}{l}\text { Investment in equity } \\
\text { accounted }\end{array}$ & & 1343 & 0 & 0 & \\
\hline
\end{tabular}




\begin{tabular}{|c|c|c|c|c|c|}
\hline Inventories & 6664 & 6664 & 0 & 0 & \\
\hline Trade receivables & 40453 & 40353 & 100 & 0.25 & 4 \\
\hline Unbilled revenue & 8514 & 8514 & 0 & 0 & \\
\hline $\begin{array}{l}\text { Cash and cash } \\
\text { Equivalents }\end{array}$ & 39270 & 39270 & 0 & 0 & \\
\hline Net tax assets & 3632 & 4486 & $(854)$ & $(23.51)$ & 5 \\
\hline Other assets & 13980 & 15379 & (1399) & $(10.01)$ & $2(a), 4,9,10,13$ \\
\hline Total Assets & 212327 & 215235 & (2908) & $(\mathbf{1 . 3 7 )}$ & \\
\hline $\begin{array}{l}\text { Share capital and share } \\
\text { premium }\end{array}$ & 28296 & 28296 & 0 & 0 & \\
\hline $\begin{array}{lr}\text { Share } & \text { application } \\
\text { money } & \text { pending } \\
\text { allotment } & \end{array}$ & 40 & 0 & 40 & 100 & 12 \\
\hline Retained earnings & 87908 & 94728 & $(6820)$ & (7.76) & \\
\hline $\begin{array}{l}\text { Cash flow hedging } \\
\text { reserve }\end{array}$ & $(1097)$ & (1097) & 0 & 0 & \\
\hline Other reserves & 1807 & 3658 & $(1851)$ & $(102.43)$ & $3,7,11$ \\
\hline Total Equity & 116954 & 125585 & $(8631)$ & (7.38) & \\
\hline Minority Interest & 116 & 0 & 116 & 100 & 11 \\
\hline Loan and Borrowings & 44850 & 44850 & 0 & 0 & \\
\hline Trade Payables & 27873 & 27873 & 0 & 0 & \\
\hline Unearned revenues & 4269 & 4269 & 0 & 0 & \\
\hline $\begin{array}{l}\text { Other liabilities and } \\
\text { provisions }\end{array}$ & 18265 & 12658 & 5607 & 30.7 & $6,8,10,12$ \\
\hline Total Liabilities & 95373 & 89650 & 5723 & 6 & \\
\hline $\begin{array}{lll}\begin{array}{l}\text { Total liabilities and } \\
\text { equity }\end{array} & \\
\end{array}$ & 212327 & 215235 & (2908) & $(1.37)$ & \\
\hline
\end{tabular}

Source: Annual Report of Wipro, 2010, p170-71.

\section{Notes}

1. Under IFRS, the amortization charge in respect of finite life intangible assets is recorded in proportion of economic benefits consumed during the period to the expected total economic benefits from the intangible asset. Under Previous GAAP, finite life intangible assets are amortized usually on a straight line basis over their useful life. As a result, the accumulated amortization under IFRS is lower by INR 101as at April 1, 2010.

2. Listed below are the key differences in property, plant and equipment between IFRS and Previous GAAP:

a. Under IFRS, leases of land are classified as operating leases unless the title to the leasehold land is expected to be transferred to the Company at the end of the lease term. Lease rentals paid in advance and lease deposits are recognized as other assets. Under Previous GAAP, the lease rentals paid in advance and lease deposits are recognized in property, plant and equipment. Under IFRS, INR 645 of such payments towards lease of 
land has been reclassified from property, plant and equipment to other assets. This adjustment has no impact on equity.

b. Difference in the basis of interest capitalization between Previous GAAP and IFRS resulted in higher interest capitalization by INR 305 under IFRS, net of related depreciation impact.

3. Under IFRS, available for sale investments are measured at fair value at each reporting date. The changes in fair value of such investments, net of taxes, are recognized directly in equity. Under Previous GAAP, short-term investments are measured at lower of cost or fair value. Consequently, carrying value of the available for sale investments under IFRS is higher by INR 568 (tax effect INR 165).

4. Under IFRS, an entity is required to allocate revenue to separately identifiable components of a multiple deliverable customer arrangement. The revenue relating to these components are recognized when the appropriate revenue recognition criteria is met. Under IFRS, in respect of multiple element arrangements comprising delivered products and installation services, the Company defers and recognizes revenue relating to installation services when those services are rendered. Under Previous GAAP, installation services are considered to be incidental / perfunctory to product delivery. Entire revenue is recognized, when the products are delivered in accordance with the contractual terms, and expected cost of installation services is also accrued. Consequently, under IFRS the Company has unearned revenue of INR 100 and reversed INR 78 of cost accrued for installation services. The deferred revenues are recognized when the related installation services is performed.

5. Under IFRS, tax benefits from carry forward tax losses is recognized if it is probable that sufficient taxable profits would be available in the future to realize the tax benefits. Under Previous GAAP, deferred tax asset in respect of carry forward tax losses is recognized if it is virtually certain that sufficient future taxable income would be available in the future to realize the tax benefits. Further, Previous GAAP requires an entity to follow the income statement approach for recognizing deferred taxes, while IFRS mandates the balance sheet approach in recognizing deferred taxes. As a result, net deferred tax assets under IFRS are higher by INR 854.

6. Under Previous GAAP, a liability is recognized in respect of proposed dividend on Company's equity shares, even though the dividend is expected to be approved by the shareholders subsequent to the reporting date. Under IFRS, liability for dividend is recognized only when it is approved by shareholders. Accordingly, provisions under IFRS are lower by INR 6,842.

7. The Company grants share options to its employees. These share options vest in a graded manner over the vesting period. Under IFRS, each tranche of vesting is treated as a separate award and the stock compensation expense relating to that tranche is amortized over the vesting period of the underlying tranche. This results in accelerated amortization of stock compensation expense in the initial years following the grant of share options. Previous GAAP permits an entity to recognize the stock compensation expense, relating to share options which vest in a graded manner, on a straight-line basis over the requisite vesting period for the entire award. However, the amount of compensation cost recognized at any date must at least equal the portion of the grantdate value of the award that is vested at that date. Accordingly, the stock compensation expense recognized under IFRS is higher by INR 1,332 as at April 1, 2010 in respect of the unvested awards.

8. Under IFRS, contingent consideration relating to acquisitions is recognized if it is probable that such consideration would be paid and can be measured reliably. Under Previous GAAP, contingent consideration is recognized after the contingency is resolved 
and additional consideration becomes payable. As a result, under IFRS, the Company has recognized INR 426 of contingent consideration as additional goodwill and liability. This adjustment has no impact on equity.

9. Under IFRS, loans and receivables are recognized at amortized cost, which is carried at historical cost under Previous GAAP. As a result, the carrying value of such loans and receivables under IFRS is lower by INR 154.

10. Indian tax laws, levies Fringe benefit Tax (FBT) on all stock options exercised on or after April 1, 2009. The Company has modified share options plan to recover FBT from the employees. Under IFRS 2, Share based payment, the FBT paid to the tax authorities is recorded as a liability over the period that the employee renders services. Recovery of the FBT from the employee is accounted as a reimbursement right under IAS 37, Provisions, contingent liabilities and contingent assets, as it is virtually certain that the Company will recover the FBT from the employee. Accordingly, under IFRS, the Company has recognized the reimbursement right as a separate asset, not to exceed the FBT liability recognized at each reporting period. Under Previous GAAP, FBT liability and the related FBT recovery from the employee is recorded the time of exercise of stock option by the employee. Accordingly, under IFRS the Company has recognized INR 766 as other liabilities and reimbursement right in respect of outstanding stock options. This adjustment has no impact on equity.

11. Under IFRS, minority interest is reported as a separate item within equity, whereas previous GAAP requires minority interest to be presented separately from equity.

Table 6. Consolidated Financial Statements under IFRS - WIPRO Limited Reconciliation of Equity as at March 31, 2011

\begin{tabular}{|c|c|c|c|c|c|}
\hline Particulars & $\begin{array}{l}\text { Amount } \\
\text { as per } \\
\text { Previous } \\
\text { IGAAP }\end{array}$ & \begin{tabular}{l}
\multicolumn{2}{l}{ Amount } \\
as per \\
IFRS
\end{tabular} & $\begin{array}{l}\text { Effect of } \\
\text { Transaction } \\
\text { to IFRS }\end{array}$ & $\begin{array}{l}\text { \% of } \\
\text { Change }\end{array}$ & $\begin{array}{l}\text { Relevant for } \\
\text { Notes for } \\
\text { adjustments }\end{array}$ \\
\hline Goodwill & 56521 & 56143 & 378 & 0.67 & 1,10 \\
\hline $\begin{array}{ll}\text { PPE } & \text { and } \\
\text { Intangibles } & \end{array}$ & 52563 & 53287 & (724) & $(1.38)$ & $1,2,3$ \\
\hline $\begin{array}{l}\text { Available for Sales } \\
\text { investment }\end{array}$ & 16426 & 16293 & 133 & 0.81 & 4 \\
\hline $\begin{array}{l}\text { Investment in } \\
\text { equity accounted }\end{array}$ & 1670 & 1670 & 0 & 0 & \\
\hline Inventories & 7587 & 7587 & 0 & 0 & \\
\hline Trade receivables & 50370 & 50123 & 247 & 0.49 & 5 \\
\hline Unbilled revenue & 14108 & 14108 & 0 & 0 & \\
\hline $\begin{array}{l}\text { Cash and cash } \\
\text { Equivalents }\end{array}$ & 49117 & 49117 & 0 & 0 & \\
\hline Net tax assets & 2672 & 5759 & $(3087)$ & $(115.53)$ & 6 \\
\hline Other assets & 20984 & 23203 & $(2219)$ & $(10.57)$ & 3(a), $, 5,9,13$ \\
\hline Total Assets & 272018 & 277290 & (5272) & (1.94) & \\
\hline $\begin{array}{l}\text { Share capital and } \\
\text { share premium }\end{array}$ & 29667 & 29667 & 0 & 0 & \\
\hline $\begin{array}{l}\text { Share application } \\
\text { money pending } \\
\text { allotment }\end{array}$ & 15 & 0 & 15 & 100 & 12 \\
\hline Retained earnings & 119957 & 126646 & $(6689)$ & $(5.58)$ & \\
\hline
\end{tabular}




\begin{tabular}{|l|l|l|l|l|l|}
\hline $\begin{array}{l}\text { Cash flow } \\
\text { hedging reserve }\end{array}$ & $(16886)$ & $(14533)$ & $(2353)$ & 13.93 & 6 \\
\hline Other reserves & 3546 & 5601 & $(2055)$ & $(57.95)$ & $4,8,11$ \\
\hline Total Equity & $\mathbf{1 3 6 2 9 9}$ & $\mathbf{1 4 7 3 8 1}$ & $\mathbf{( 1 1 0 8 2 )}$ & $\mathbf{( 8 . 1 3 )}$ & \\
\hline Minority Interest & 237 & 0 & 237 & 100 & 11 \\
\hline $\begin{array}{l}\text { Loan and } \\
\text { Borrowings }\end{array}$ & 56892 & 56892 & 0 & 0 & \\
\hline Trade Payables & 40191 & 40191 & 0 & 0 & \\
\hline Unearned revenues & 8734 & 8734 & 0 & 0 & $7,9,10,11,13$ \\
\hline $\begin{array}{l}\text { Other liabilities } \\
\text { and provisions }\end{array}$ & 29665 & 24092 & 5573 & 18.79 & \\
\hline Total liabilities & $\mathbf{1 3 5 7 1 9}$ & $\mathbf{1 2 9 9 0 9}$ & $\mathbf{5 8 1 0}$ & $\mathbf{4 . 2 8}$ & \\
\hline
\end{tabular}

Table 6. Consolidated Financial Statements under IFRS - WIPRO Limited

Reconciliation of Equity as at March 31, 2011

Source: Annual Report of Wipro, 2011.

\section{Notes}

1. Under IFRS, all the assets and liabilities arising from a business combination are identified and recorded at fair value. Accordingly, a portion of purchase price is allocated towards customer related intangible in respect of business combination consummated subsequent to the Transition date. Under Previous GAAP, assets and liabilities arising from a business combination are recognized at carrying value in the books of the acquired entity. Internally generated intangible assets would not have been recognized by the acquired entity and therefore customer related intangible arising from the business combination is not recognized under Previous GAAP. Accordingly, goodwill under IFRS is lower by INR 1,139 (net of deferred taxes) and intangible assets are higher by INR 1,535 (net of amortization of INR 91).

2. Under IFRS, the amortization charge in respect of finite life intangible assets is recorded in the proportion of economic benefits consumed during the period to the expected total economic benefits from the intangible asset. Under Previous GAAP, finite life intangible assets are amortized usually on a straight line basis over their useful life. As a result the accumulated amortization under IFRS is lower by INR 149 as at March 31, 2011.

3. Listed below are the key differences in property, plant and equipment between IFRS and Previous GAAP:

a. Under IFRS, leases of land are classified as operating leases unless the title to the leasehold land is expected to be transferred to the Company at the end of the lease term. Lease rentals paid in advance and lease deposits are recognized as other assets. Under Previous GAAP, the lease rentals paid in advance and lease deposits are recognized in property, plant and equipment. Under IFRS, INR 1,293 of such payments towards lease of land has been reclassified from property, plant and equipment to other assets. This adjustment has no impact on equity.

b. Difference in the basis of interest capitalization between Previous GAAP and IFRS resulted in higher interest capitalization by INR 331 under IFRS, net of related depreciation impact.

4. Under IFRS, available for sale investments are measured at fair value at each reporting date. The changes in fair value of such investments net of taxes are recognized directly in equity. Under Previous GAAP, short-term investments are measured at lower of cost or fair value. Consequently, available for sale investments under IFRS is higher by INR 
(tax effect INR 33). Additionally, investment in non-convertible debentures amounting to INR 250 is classified as investments under Previous GAAP whereas the same is shown under other assets in IFRS. This has no impact on equity.

5. Under IFRS, an entity is required to allocate revenue to separately identifiable components of a multiple deliverable customer arrangement. The revenue relating to these components are recognized when the appropriate revenue recognition criteria is met. Under IFRS, in respect of multiple element arrangements comprising delivered products and installation services, the Company defers and recognizes revenue relating to installation services when those services are rendered. Under Previous GAAP, installation services are considered to be incidental / perfunctory to product delivery. Entire revenue is recognized, when the products are delivered in accordance with the contractual terms, and expected cost of installation services is also accrued. Consequently, under IFRS the Company has deferred revenue of INR. 247 and reversed INR. 195 of cost accrued for installation services. The deferred revenues are recognized when the related installation services is performed.

6. Under IFRS, tax benefits from carry forward tax losses is recognized if it is probable that sufficient taxable profits would be available in the future to realize the tax benefits. Under Previous GAAP, deferred tax asset in respect of carry forward tax losses is recognized if it is virtually certain that sufficient future taxable income would be available in the future to realize the tax benefits. Further, Previous GAAP requires an entity to follow the income statement approach for recognizing deferred taxes, while IFRS mandates balance sheet approach in recognizing deferred taxes. As a result, net deferred tax assets under IFRS are higher by INR. 3,087 (including impact of foreign currency translation adjustment, where necessary).

7. Under Previous GAAP, liability is recognized in respect of proposed dividend on Company's equity share, even though the dividend is expected to be approved by the shareholders subsequent to the reporting date. Under IFRS, liability for dividend is recognized only when it is approved by shareholders. Accordingly, provisions under IFRS are lower by INR 6,856.

8. The Company grants share options to its employees. These share options vest in a graded manner over the vesting period. Under IFRS, each tranche of vesting is treated as to that tranche is amortized over the vesting period of the underlying tranche. This results in accelerated amortization of stock compensation expense in the initial years following grant of share options. Previous GAAP permits an entity to recognize the stock compensation expense, relating to share options which vest in a graded manner, on a straight-line basis over the requisite vesting period for the entire award. However, the amount of compensation cost recognized at any date must at least equal the portion of the grant-date value of the award that is vested at that date. Accordingly, the stock compensation expense recognized under IFRS is higher by INR 1,432 as at March 31, 2011 , in respect of unvested awards.

9. Indian tax laws levy Fringe Benefit Tax (FBT) on all stock options exercised on or after April 1, 2009. The Company has modified share options plan to recover FBT from the employees. Under IFRS 2, Share based payment; the FBT paid to the tax authorities is recorded as a reimbursement right under IAS 37, Provisions, contingent liabilities and contingent assets, as it virtually certain that the Company will recover the FBT from the employee. Accordingly, under IFRS, the Company has recognized the reimbursement right as a separate asset, not to exceed the FBT liability recognized at each reporting period. Under Previous GAAP, FBT liability and the related FBT recovery from the employee is recorded at the time of exercise of stock option by the employee. Accordingly, under IFRS, the Company has recognized INR 741 as other liabilities and 
reimbursement right in respect of outstanding stock options. This adjustment has no impact on equity.

10. Under IFRS, contingent consideration relating to acquisitions is recognized if it is probable that such consideration will be paid and can be measured reliably. Under Previous GAAP, contingent consideration is recognized after the contingency is resolved and additional consideration becomes payable. As a result, under IFRS, the Company has recognized INR 761 of contingent consideration as additional goodwill and liability. This adjustment has no impact on equity.

11. Under IFRS, minority interest is reported as a separate item within equity, whereas Previous GAAP requires minority interest to be presented separately from equity. This presentation difference between IFRS and Previous GAAP has resulted in an increase in equity under IFRS by INR 237 as at March 31, 2011.

12. Under IFRS, share application money received and pending allotment is reported under other liabilities, whereas Previous GAAP requires share application money pending allotment to be presented as a separate item within equity. This presentation difference between IFRS and Previous GAAP has resulted in a decrease in equity under IFRS by INR 15 as at March 31, 2011.

13. Difference in accounting for certain foreign currency forward contract has resulted in a decrease in other assets by INR 260 and other liabilities by INR 236 under IFRS as of March 31, 2011.

Evaluating the closing financial statement of Wipro for the year 31.3.2011 it is observed there is $1.94 \%$ increase in the Total assets value as per IFRS when compared with the total assets value as per Indian Accounting standards. There is increase in the value of Net tax asset including deferred taxes in IFRS reporting by $115.53 \%$ when compared with the amount reported under Indian Accounting Standard. There is $10.57 \%$ increase in other assets in IFRS reporting compared to Indian Accounting standards. The total equity has increased by nearly $8.13 \%$ in IFRS when compared to the Indian accounting standards. The total liability has decreased by $4.28 \%$ in IFRS when compared to Indian accounting standards.

Table 7. Reconciliation of Profit for the Year Ended March 31, 2011

\begin{tabular}{|c|c|c|c|c|}
\hline Particulars & $\begin{array}{l}\text { Amount as per } \\
\text { Previous GAAP }\end{array}$ & $\begin{array}{l}\text { Effect of Transition } \\
\text { to IFRS }\end{array}$ & $\begin{array}{l}\text { Amount as per } \\
\text { IFRS }\end{array}$ & $\begin{array}{l}\text { Relevant Notes } \\
\text { for adjustments }\end{array}$ \\
\hline Revenues & INR 256,995 & INR (104) & INR 256,891 & 1 \\
\hline Cost of revenues & $(179,230)$ & $(985)$ & $(180,215)$ & $1,2,5$ \\
\hline Gross profit & 77,765 & $(1,089)$ & 76,676 & \\
\hline $\begin{array}{l}\text { Selling and marketing } \\
\text { expenses }\end{array}$ & $(17,853)$ & 540 & $(17,313)$ & $1(\mathrm{c}), 2,3,5$ \\
\hline $\begin{array}{l}\text { General and } \\
\text { administrative } \\
\text { expenses }\end{array}$ & $(14,356)$ & (154) & $(14,510)$ & 2,5 \\
\hline $\begin{array}{l}\text { Foreign exchange } \\
\text { gains/(losses), net }\end{array}$ & $(1,553)$ & 0 & $(1,5553)$ & \\
\hline $\begin{array}{l}\text { Results from operating } \\
\text { activities }\end{array}$ & 44,004 & (704) & 43,300 & \\
\hline Finance expense & $(3,865)$ & 41 & $(3,824)$ & \\
\hline $\begin{array}{l}\text { Finance and other } \\
\text { income }\end{array}$ & 5,057 & 0 & 5,057 & \\
\hline $\begin{array}{l}\begin{array}{l}\text { Share of profits of } \\
\text { equity } \\
\text { investees }\end{array} \\
\end{array}$ & 362 & 0 & 362 & \\
\hline Profit before tax & 45,558 & $(6630$ & & \\
\hline \multicolumn{5}{|l|}{ Income tax expense } \\
\hline \multicolumn{5}{|l|}{ Profit for the year } \\
\hline Attributable to: & & & & \\
\hline
\end{tabular}




\begin{tabular}{|l|l|l|l|l|}
\hline $\begin{array}{l}\text { Equity holders of the } \\
\text { Company }\end{array}$ & & & & \\
\hline Minority Interest & & & & \\
\hline
\end{tabular}

Source: Annual Report of Wipro, 2011

\section{Notes}

The following are the primary differences in revenue between IFRS and Previous GAAP:

a. Under Previous GAAP, revenue is reported net of excise duty charged to customers. Under IFRS, revenue includes excise duty charged to customers. As a result, revenues and cost of revenues under IFRS is higher by INR 1,055.

b. Under IFRS, revenue relating to product installation services is recognized when the installation services are performed. Under Previous GAAP, the entire revenue relating to the supply and installation of products is recognized when products are delivered in accordance with the terms of contract. Installation services are considered to be incidental to product delivery and the cost of installation services is accrued upon delivery of the product. Accordingly, revenue and cost of revenue under IFRS is lower by INR 147 and INR 117, respectively.

c. Under IFRS, generally cash payments to customers pursuant to sales promotional activities are considered as sales discounts and reduced from revenue. Under Previous GAAP, such payments are considered as cost of revenue and selling and marketing expense. As a result, under IFRS, revenue is lower by INR 1,011 and cost of revenues and selling and marketing expenses are lower by INR 275 and INR 736, respectively.

Under IFRS, the Company amortizes stock compensation expense, relating to share options, which vest in a graded manner, on an accelerated basis. Under Previous GAAP, the stock compensation expense is recorded on a straight-line basis. As a result, under IFRS the Company has recognized additional stock compensation expense of INR 40 in cost of revenue, INR 30 in selling and marketing expenses and INR30 in general and administrative expenses.

Under IFRS, the amortization charge in respect of finite life intangible assets is recorded in the proportion of economic benefits consumed during the period to the expected total economic benefits from the intangible asset. Under Previous GAAP, such finite life intangible assets are amortized on a straight-line basis over the life of the asset. Further, the Company recorded additional amortization in respect of customer related intangible arising out of business combination consummated subsequent to the Transition date. Accordingly, amortization under IFRS is higher by INR 43.

This includes difference in accounting for certain foreign currency forward contracts and basis of interest capitalization under IFRS and Previous GAAP.

Under Indian tax laws, the Company is required to pay Fringe Benefit Tax (FBT) on certain expenses incurred by the Company. Under Previous GAAP, FBT is reported in the income statement as a separate component of income tax expense. Under IFRS, FBT does not meet the definition of income tax expense and is recognized in the related expense line items. Accordingly, the cost of revenue, selling and marketing expenses and general and administrative expenses under IFRS are higher by INR 165, INR 124 and INR 124, respectively and income tax expense is correspondingly lower. 


\section{Impact of Convergence to IFRS on Financial Ratios}

Researcher have examined five ratios that depends on financial statements for the year as at March 31, 2011

1. Return on Equity defined as net income divided by book value of equity;

2. Return on Assets, defined as net income divided by total assets;

3. Total Asset Turnover, defined as sales revenue divided by total assets;

4. Leverage, defined as total liabilities divided by book value of equity

5. Net Profit ratio defined as Net income divided by sales revenue.

Table 7: Financial Ratios for the year ended 31st March 2011 of WIPRO Ltd.

\begin{tabular}{|l|l|l|}
\hline RATIO & As Per IGAAP & As Per IFRS \\
\hline Return on Equity & 0.29 & 0.26 \\
\hline Return on Asset & 0.14 & 0.14 \\
\hline Total asset turnover & 0.94 & 0.93 \\
\hline Leverage & 1 & 0.88 \\
\hline Net Profit Ratio & 0.15 & 0.15 \\
\hline
\end{tabular}

Source: Annual Report of Wipro Limited. 2011.

The author examine that the Return on Equity and Net profit ratio as reported under IGAAP and IFRS remains the same. There is a decrease in the leverage or debt equity ratio in IFRS accounting when compared to IGAAP accounting. The reduction in this ratio in IFRS is due to increase in value of Equity by $8.13 \%$ in IFRS accounting and reduction in value of Total Liabilities by about $4.28 \%$ in IFRS accounting when compared with IGAAP accounting. There is reduction in return on equity mainly because of increase in the equity value by about $8.13 \%$ and decrease in Net profit by about $0.61 \%$ in IFRS reporting when compared to IGAAP reporting. There is reduction in Total asset Turnover mainly because of increase in Total assets by about $1.94 \%$ and decrease in turnover by about $0.04 \%$ in IFRS reporting when compared with IGAAP reporting.

\section{CONCLUSIONS}

The study investigates empirically the effect of voluntary adoption and convergence of IGAAP with IFRS. It has been found from our study that there is not much deviations and fluctuations in the net income position as disclosed by financial statement of Wipro Ltd in IFRS reporting and Indian GAAP. But deviation is rather prominent when observing the total liability and equity position which is mainly because of reclassification between equity and total liability. The provision under IFRS is reduced mainly because dividend provision is not recognized in IFRS. Fair value measurement of Available for sale investment and the share compensation expense recognized in IFRS is higher, as in IFRS reporting accelerated amortization of stock compensation expense in the initial years following the grant of options, whereas in Indian GAAP reporting recognizes the stock compensation expenses in graded manner on a straight line basis over the requisite vesting period for the entire award which resulted in increase in share based payment reserve. In true generalized sense, the return on equity, return on asset, total asset turnover and net profit ratio are not significantly affected by converging to IFRS but the leverage ratio shows significant change on converging with IFRS. There are also significant changes in the total equity and total liability position on convergence to IFRS but not prominent changes in the total asset position.

The study suffers with some limitations also. The content discussed in this article is drawn, by and large, from secondary sources, i.e., journal articles, magazines, newspapers, annual report 
etc. The study is qualitative as well as quantitative in nature but there is less possibility of judging or analyzing the data on basis of our own best judgment because readymade comparative analysis of financial statement of Wipro Ltd under IFRS and IGAAP has been considered in the study due to difficulty in examining the issues through quantitative tools at the very budding stage of this adoption process.

In summary, it can be said that differences in accounting methods create information costs for the preparers, auditors, and users of financial statements. Several organizations recognized the need to harmonize financial reporting, and the European Union was one of the first to publish directives to reduce differences in the reporting of similar transactions. Convergence in India would be facilitated by the fact that historically Indian accounting standards have been based on principles as against rules. However, given the nature of accounting and peculiarities of the Indian economic environment, the process of convergence has its own set of challenges. The conflicting legal and regulatory requirements related to financial statements, the technical preparedness of industry and accounting professionals and the economic environment prevailing in the country will pose challenges to this convergence. Given the task and challenges, all the entities should ensure that their convergence plan are designed in such a way as to achieve the objective of doing it once, but doing it right.

\section{References}

Ali, A. and Hwang, L., Country-specific factors related to financial reporting and the value relevance of accounting data. Journal of Accounting Research, 2000. 38(1): p. 1-21.

Armstrong, S, Christopher, Barth, E, Mary, Jagolinzer, D, Alan, Riedl and J, Edward, Market Reaction to the adoption of IFRS in Europe', The Accounting Review, 2010. 85(1): p. 31-61.

Barth, M. E., Landsman W. R., Lang, M. H. and Williams, C. D., Accounting quality: International

Accounting standards and US GAAP, SSRN, 2008.

Benzacar, K., IFRS- the Next Accounting Revolution CMA Management publication.

Brian B. Stanko and Thomas L. Zeller, Arrival of A New GAAP: International Financial Reporting Standards, Journal of Business \& Economics Research, October, 2010.8 (10).

Chand, Pramod and White, Michael, 'A critique of the influence of globalization and convergence of accounting standards in Fiji', Critical Perspective on Accounting, 2007. 18 (5): p. 605.

Chen.C. J, Chen. S and Su. X., Is Accounting Information Value-Relevant in the Emerging Chinese Stock Market. Journal of International Accounting Auditing and Taxation, 2010.10: p.1-22.

Capkun V. Jeny A.C Jeanjean T. and Weiss L.A, "Earnings management and value relevance during the Mandatory Transition from Local GAAP to IFRS in Europe" available at

http://ssrn.com/abstract=1125716, retrieved on 5 August 2010.

Callao, Susana, Jarne, I, José, Laínez and A, José, 'Adoption of IFRS in Spain: Effect on the comparability and relevance of financial reporting', Journal of International Accounting Auditing \& Taxation, 2007. 16 (2): P.148.

Devalle, Alain, Onali, Enrico and Magarini, Riccardo, 'Assessing the Value Relevance of Accounting Data After the Introduction of IFRS in Europe', Journal of International Financial Management \& Accounting, 2010.21 (2): p. 85.

Ghosh T. P., -IFRSs Adoption in India: A Review of Regulatory and Accounting Issues, Journal of Company Secretariat, 2010.

Epstein, J, Barry, 'The Economic Effects of IFRS Adoption', the CPA Journal, 2009.79 (3): p. 26-31. 
Elena, Hlaciuc, Catalina, Camelia, Mihalciuc, Stefana, Irina, Cibotariu, Niculina and Anisoara, Apetri, 'Some Issues About the Transition from U.S. Generally Accepted Accounting Principles (GAAP) To International Financial Reporting Standards (IFRS)', Annales Universitatis Apulensis: Series Oeconomica, 2009. 11 (1): p. 275-289.

Hope O.k Jin and Kang, "Empirical Evidence on Jurisdictions that Adopt IFRS', 2006. Available at http://ssrn.com/abstract=751264 retrieved on 7 August 2010.

Iatridis, George, 'IFRS Adoption and Financial Statement Effects: The UK Case', International Research Journal of Finance and Economics, 2010. (38): p.165-172.

Jun-Ke Liu and 2Ying-Ju Sun, Game Analysis of the Equity Incentive Mechanism of Listed Company, Advance in Applied Economics and Finance, 2012.1(3): p.197-201.

Kothari, S. P., The role of financial reporting in reducing financial risks in the market. Paper presented at the Federal Reserve Bank of Boston in its Journal Conference Series, 2000.

Lantto A.M and Sahlstrom P, "Impact of International Financial Reporting Standard Adoption on Key Financial Ratio", Accounting and Finance, 2009. 49: p. 341-361.

Lantto A.M, Does IFRS improve the usefulness of accounting information on code law country?' 2007. Available at http:// ssrn.com/abstract=905218 retrieved on 10 August 2010.

Mingyi Hung and K.R. Subramanyam, "Financial Statement Effects of Adopting IFRS: The case of Germany, 2004. Available at http://ssrn.com/abstract=622921.

Paananen, Mari and Lin, Henghsiu, 'the Development of Accounting Quality of IAS and IFRS over Time: The Case of Germany', Journal of International Accounting Research, 2009.8 (1): p. 31-55.

Rui-zhiWu and Lu-ying Hao, An Empirical Study on Impacts of China Listed Companies' Intangible Assets to Operating Performance, Advances in Applied Economics and Finance, 2012. 1 (3): p.149-52.

Ray, Sarbapriya, and Applicability of International Financial Reporting Standards in India: Some Key Issues and Challenges, Journal of Expert Systems, 2012.1(1): p.1-15.

Stent W, Bradbury M. and Hooks J., "IFRS in New Zealand: Effects on Financial Statements and Ratios", Pacific accounting Review, 2010. 22 (2): p.92-107.

Sujatha B, Accounting Standards in India: Towards convergence published by ICFAI

Steffee, S, 'IFRS Discrepancies Vary by Country, Company', the Internal Auditor, 2009. 66 (4): p.13

Tripati, R and Gupta, S, International Financial Reporting Standard: Away to global consistency, Australian Journal of Business and Management Research, 2011.1(1): p.38-51.

Xi Zhao and Ying-Jun Sun, Performance Change and Its Influence Factors in IPO- An Empirical Study on China Growth Enterprise Market, Advance in Applied Economics and Finance, 2012. 1(4): p.202-206.

Xi Zhao1 and Ying-Jun Sun, an Empirical Study of Chinese Treasury Bonds Scale in the Background of European Debt Crisis, Advances in Applied Economics and Finance, 2012. 1(3): p.153-58.

Zhou, Haiyan, Xiong, Yan and Ganguli, Gouranga, 'Does The Adoption Of International Financial Reporting Standards Restrain Earnings Management? Evidence from an Emerging Market', Academy of Accounting and Financial Studies Journal, 2009. 13 (Special Issue): p.43-56.

Zakari, M.I., and “IFRS as a tool for Cross-Border Financial Reporting” A paper Presented at ICAN Conference on IFRS, 2010.

http:// www.article base.com/accounting-articles/working towards a global convergence of accounting standars-1379167.html

IFRS: A quick reference Guide by Robert Krik

http://online library.wiley.com/doi/10.1002/jcaf.20406/abstract

http://icai.org/resource

http://www.pwc.com/en-GX/gx/ifrs-reportingservices/pdf/viewpoint_convergence.pdf 39

Annual Reports of Wipro, 2010, 2011 and 2012. 